\title{
SCIENTIFIC RETRACTION: A SYNONYM FOR PSEUDOSCIENCE?
}

\author{
Bhavisha P. Sheth ${ }^{1}$, Vrinda S. Thaker ${ }^{1}$
}

\begin{abstract}
The phenomenon of scientific retraction is a shameful act for the scientific community, but a necessity to maintain the purity of science. The two main causes for retractions include plagiarism and research misconduct. The post retraction citation of articles is again a repetition of inappropriateness. Hence the editorial, peer review policies should be revised and the retractions should be publicized more to avoid the citation of the invalid literature. Also, the scientific readership has a responsibility to evaluate the scientific validity of published studies.
\end{abstract}

Key words: retraction, plagiarism, misconduct, citation

\section{Retractación científica: ¿̨un sinónimo de seudociencia?}

Resumen: El fenómeno de la retractación científica constituye una vergüenza para la comunidad científica, pero es necesario para mantener la pureza de la ciencia. Las dos causas principales de retractación son el plagio y faltas en la conducta de investigación. La citación de artículos posterior a su retractación es, de nuevo, una repetición inapropiada. Por lo tanto, la editorial y las normas de evaluación por pares debieran revisarse y las retractaciones publicarse más para evitar las citaciones de literatura inválida. También los lectores científicos tienen la responsabilidad de evaluar la validez científica de los estudios publicados.

Palabras clave: retractación, plagio, faltas en la conducta de investigación, citación

\section{Retrataçáo científica: um sinônimo de pseudociência?}

Resumo: O fenômeno de retratação científica é uma vergonhosa atitude para a comunidade científica, mas uma necessidade para manter a pureza da ciência. As duas principais causas para a retratação incluem o plágio e a má conduta na pesquisa. A citação após retratação de artigos é novamente uma repetida inadequação. Daí porque o editorial e a política de revisão por pares devem ser revistas e as retrataçóes deveriam ser mais divulgadas para evitar uma citaçáo inválida da literatura. Ademais, o revisor científico tem uma responsabilidade de avaliar a validade científica dos estudos publicados.

Palavras-chave: retratação, plágio, má conduta, citação

\footnotetext{
${ }^{1}$ Department of Biosciences, Saurashtra University, Rajkot Gujarat, India Correspondence: bhavisha.sheth@gmail.com
} 
Science (from the Latin scientia, meaning "knowledge") is an endeavor that systematizes knowledge in the form of testable explanations and predictions of the worldly facts(1). Scholastic publishing is the process of placing the results of one's research into the literature. Publication in scholarly journals is an essential part of the scientific research process(2). The purpose of it being the updating and sharing of knowledge in broad sense along with other implicit factors like funding, carrier advancement, competitive grants, awards etc.(3). Every discipline relies on the integrity of its literature. The implicit assumption about the authors is that their contributions to journals reflect their meticulousness and honesty. Everybody concerned to the discipline has a vested interest in the accuracy and authenticity of what is communicated. Henceforth all the literature resources maintain high standards to ensure the legitimacy of the research and scientific con$\operatorname{duct}(4)$.

In general, a retraction of a published scientific article indicates that the original article should not have been published and that its data and conclusions should not be used as part of the foundation for future research. Retractions always negate the author's previous public support for the original statement. They typically indicate a major problem with the research of enough significance to invalidate its findings. As such, they represent a threat both to the integrity of the scientific literature and to any future studies based on the erroneous conclusions(5). It is a shameful phenomenon for the scientific community as a whole; as ethics are the base of science and breaching those indicate pseudoscience and dishonesty.

\section{Causes and statistical implications}

Approximately, 1.4 million papers are published every year, only a few of them are retracted and fewer coming to the notice of the public. According to the data from Thomson Reuters "Web of Science" database, courtesy of Times Higher Education, five out of 689752 were retracted in 1990, which rose to the retraction of 95 papers out of 1.4 million papers published in 2008. So, the retractions are increasing rapidly, in line with the number of publications. Figure 1 shows the exponential increase in the Pubmed retractions from 1977 to 2010(6).

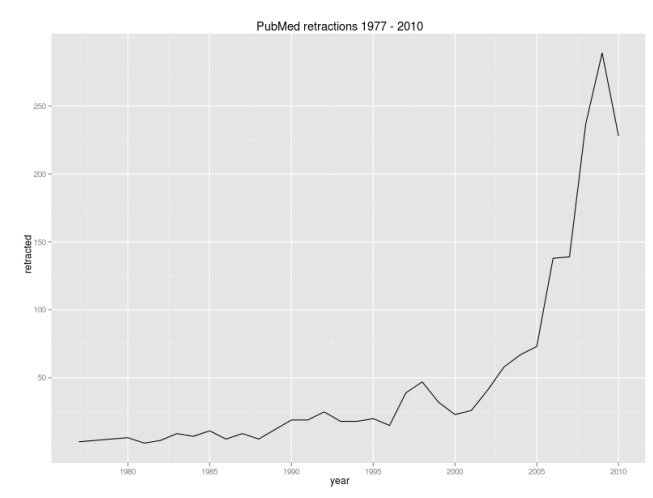

Figure 1: The plot here shows exponential increase in the $\mathrm{n}^{\circ}$ of retraction (Y axis) from 19772010 (X Axis)

But closer research shows that growing or not, these formal retractions are likely just the tip of the iceberg $(7,8)$. Some of them are untouched of the notice of the common public.

The two main causes of retractions of scientific published articles are research error or misconduct and plagiarism. The former in the form of inefficiency of the author to reproduce the results. A more detailed explanation is as follows:

- Misconduct was classified, using the definitions of scientific misconduct from the US Office of Science and Technology Policy, as either fabrication (making up data or results and recording or reporting on them); falsification (manipulating research materials, equipment, or processes; or changing or omitting data or results such that the research is not accurately represented in the research record); or plagiarism (the appropriation of another person's ideas, processes, results, or words without giving appropriate credit).

- Mistakes were defined as reported errors in sampling, procedures, or data analysis; failure to reproduce findings or accidental omission of key information from methods or analy$\operatorname{sis}(5)$. 
Retractions for fraud (data fabrication or data falsification) may represent a purposeful effort to deceive, a motivation fundamentally different from those for error(6). Compared with an earlier study(9) of retractions for the years 1966-1994, the study by(10) found (1) a significantly higher rate of retraction $(0.0021 \%$ versus $0.0065 \%$, p, 0.0001 by test of proportions), (2) a decrease in the mean time from publication to retraction (from 28 months to 21 months), and (3) a decrease in the proportion of retractions initiated by authors (from $81 \%$ to $67 \%$ ) (see table 1), suggesting that others have become involved in oversight.

Table 1: Agents of retraction of scientific articles, and reasons for retraction(10)

\begin{tabular}{|l|l|l|}
\hline Variable & $\begin{array}{l}\text { Budd's study } \\
(\mathrm{n}=235)\end{array}$ & $\begin{array}{l}\text { Redman et al } \\
\text { study } \\
(\mathrm{n}=315)\end{array}$ \\
\hline \multicolumn{2}{|l|}{ Agent of retraction (per cent) } & 4 \\
\hline Missing & - & 48 \\
\hline All authors & 81 & 19 \\
\hline Some authors & & 17 \\
\hline Editor/publisher & 19 & 12 \\
\hline Other* & - & \\
\hline Primary reason for retraction (per cent) & 22 \\
\hline Research error & 39 & 20 \\
\hline Inability to reproduce & 16 & 17 \\
\hline Plagiarism & - & 17 \\
\hline Research misconduct & 37 a & 12 \\
\hline No reason given & - & 11 \\
\hline Other & 9 & - \\
\hline $\begin{array}{l}\text { - Category not used. } \\
\text { Attorney, editor, sponsor, institutional official often with author, } \\
\text { or not clear. } \\
\text { a Includes presumed misconduct and may include plagiarism. }\end{array}$ \\
\hline
\end{tabular}

A meta-analysis of studies on scientific misconduct showed that on average, about 2 percent of scientists admitted to have fabricated, falsified or modified data or results at least once and up to one third admitted to a variety of other questionable research practices(11). A computerized scan of the research literature has revealed a bundle of plagiarized articles where, the whole passages seem to have been copied from other papers. Based on the study, researchers estimate that there may be as many as 200,000 duplicates among some 17 million papers in leading research database Medline(12).

\section{Checkpoints in Retraction}

The actual reasons for the rising tide of retractions may be the rigorous post publication editorial process as well as the use of various plagiarism detection softwares. Plagiarism checker like iThenticate is designed to catch misconduct and plagiarism prior to submission, preventing the need for retractions. One tool developed in 2006 by researchers in Dr. Harold Garner's laboratory at the University of Texas Southwestern Medical Center at Dallas is Déjà $\mathrm{Vu}(13)$, an open-access database containing several thousand instances of duplicate publication. It is based on the use of text data mining algorithm eTBLAST(14), also developed in the same lab.

\section{Attention needed on post retraction citations}

Little is known about the ultimate scientific fate of retracted, invalid literature. The consequences of scientific retractions are the inappropriate citation of the retracted articles. The continuation of the citations of the retracted papers in literature symbolizes the inadequacy of the current methods of notification. Institutions should promote a culture of responsibility, supporting authors to provide sound articles. Reviewers and readers should raise concerns with the editor to enable prompt and appropriate investigation. If substantiated, a retraction statement or expression of concern should be publicized in both print and electronic media according to guidelines. Journals should require prospective authors to declare that they have checked their manuscript's reference list for retracted articles. We believe that if this is subsequently recognized, an erratum should be published(15). Table 2 represents citations before and after retraction, and journal impact factor (JIF), according to reasons for retraction(10). 
Table 2 Mean No of citations before and after retraction

\begin{tabular}{|l|c|c|c|}
\hline \multicolumn{4}{|l|}{ Mean number of citations } \\
\hline $\begin{array}{l}\text { Reason for } \\
\text { retraction }\end{array}$ & $\begin{array}{c}\text { Before } \\
\text { retraction }\end{array}$ & $\begin{array}{c}\text { After } \\
\text { retraction }\end{array}$ & Mean JIF \\
\hline Research error & 13.7 & 15.8 & 11.68 \\
\hline $\begin{array}{l}\text { Inability to } \\
\text { reproduce }\end{array}$ & 10.7 & 20.60 & 11.11 \\
\hline Plagiarism & 2.9 & 5.6 & 6.77 \\
\hline $\begin{array}{l}\text { Research } \\
\text { misconduct }\end{array}$ & 38.3 & 23.6 & 11.82 \\
\hline No reason given & 3.6 & 7.7 & 2.11 \\
\hline Other & 3.3 & 10.8 & 8.13 \\
\hline
\end{tabular}

\section{Buck, Wakefield Retractions: qualms on the peer review?}

Two prominent journals have retracted papers by Nobel laureate Linda Buck. These retractions, a 2006 Science paper and a 2005 Proceedings of the National Academy of the Sciences (PNAS) paper, are tied to a 2001 Nature paper that she retracted in 2008 , due to the inability "to reproduce the reported findings" and "inconsistencies between some of the figures and data published in the paper and the original data," according to the retraction. The experiments were originally performed by her post doctoral researcher Zhihua Zou, was the first author on all three papers. The research that won Buck the 2004 Nobel Prize, which she shared with olfactory researcher Richard Axel of Columbia University for their discoveries of odorant receptors and the organization of the olfactory system, was unrelated to the research in the retracted papers.

Similar is the case of Dr. Andrew Wakefield, whose 1998 findings were partly discredited in 2004 and completely retracted in January 2010 by the prestigious journal The Lancet in which they were originally published. With 11 co-authors, he claimed to have found a possible connection between one of the most common vaccines given to children (measles-mumps-rubella MMR) and autism. The impact of his study has been devastating to public health as parents became fearful of having their children given protection from childhood diseases, protection which had previously been a medical routine.

The peer-review actually begins in earnest and does not stop when a paper is published. So it is common for serious problems with a paper to be discovered only after they are published. When this happens, the journal editors should be willing to admit error and correct their mistakes. This actually builds the reputation for honesty of the respective journal. Rather than removing the "peer" from "peer review", the definition of "peer" expertise should be broadened to include experts outside the academic and professional communities who have a stake in the quality of the evidence(16).

\section{Conclusion}

Although scientific retractions may be a matter of humiliation for the authors and the journal, they help maintain the purity and integrity of the individual scientific journals, the scientific literature and science on the whole. Also they keep a check on the scientists from bending the rules regarding scientific misconduct and publication2. Afterall it is the truth which triumphs. While retractions are important, the scientific readership also has a responsibility to evaluate the scientific validity of published studies and, when necessary, correspond with the journals. The final, and most important, lesson to be learned is that ultimately, research mistakes and misconduct, like all human errors, must be seen not as sources of embarrassment or failure, but rather as opportunities for learning and improvement. 


\section{References}

1. Popper K. The Logic of Scientific Discovery (2nd English ed.). New York, NY: Routledge Classics; 2002: 3.

2. Atlas MC. Retraction policies of high-impact biomedical journals. J Med Libr Assoc. 2004, 92(2), 242-250.

3. Malaviya GN. Citation, impact factor and Indian journal of surgery. Indian J Surg 2004; 66: 371-375.

4. Budd JM, Sievert M, Schultz TR, Scoville C. Effects of article retraction on citation and practice in medicine. Bull Med Libr Assoc 1999, Oct; 87(4): 437-443.

5. Nath SB, Marcus SC, and Druss BG. Retractions in the research literature: misconduct or mistakes? Med J Aust 2006; 185: 152-154.

6. Steen RG. Retractions in the scientific literature: Do authors deliberately commit research fraud? J Med Ethics. Published online: 15 November 2010.

7. Harmon K. Impact Factor: Can a Scientific Retraction Change Public Opinion? Scientific American, March 2010.

8. Poulton A. Mistakes and misconduct in the research literature: retractions just the tip of the iceberg. Med J Aust 2007; 186(6): 323-324.

9. Budd JM, Sievert M, Schultz TR. Phenomena of retraction: reasons for retraction and citations to the publications. JAMA 1998; 280: 296-297.

10. Redman BK, Yarandi HN, Merz JF. Empirical developments in retraction. J Med Ethics 2008; 34: 807-809.

11. Fanelli D. How Many Scientists Fabricate and Falsify Research? A Systematic Review and Meta-Analysis of Survey Data. PLoS ONE 2009; 4(5): e5738.

12. Minkel JR. Scan Uncovers Thousands of Copycat Scientific Articles. Scientific American, January 30, 2008.

13. Errami M, Hicks JM, Fisher W. "Déjà vu--a study of duplicate citations in Medline”. Bioinformatics 2008; $24(2): 243-$ 249.

14. Errami M, Wren JD, Hicks JM, Garner HR. "eTBLAST: a web server to identify expert reviewers, appropriate journals and similar publications". Nucleic Acids Res 2007; 35 (Web Server issue), W12-5.

15. Drury NE, Karamanou DM. Citation of Retracted Articles: A Call for Vigilance. Ann Thorac Surg 2009; 87: 670.

16. Shashok K. Who's a peer? Improving peer review by including additional sources of expertise. J Participat Med 2010, Dec; 8(2): e15.

Received: December 15, 2012

Accepted: December 17, 2012 